\title{
Study on the microstructure of UNS S32304 duplex steel submitted to heat- treatments
}

\author{
Goulart, F. ; Ichikawa, R. U. ${ }^{1}$; Turrillas, X. ${ }^{2}$; Martinez, L. G. ${ }^{1 *}$ \\ 1 Nuclear and Energy Research Institute, IPEN/CNEN, São Paulo, SP, Brazil \\ 2 Institut de Ciència de Materials de Barcelona, ICMAB-CSIC, Barcelona, Catalunha
}

*e-mail: Igallego@ipen.br

\begin{abstract}
Duplex stainless steels are characterized by a good combination of mechanical properties and corrosion resistance. Due to the metastable equilibrium between the ferritic $(\alpha)$ and austenitic $(\mathrm{y})$ phases, significant changes in the microstructure of these steels may occur when subjected to temperatures higher than the ambient, degrading their properties. In this work, it was investigated the influence of heat treatments on the microstructure and mechanical properties of a duplex stainless steel UNS-S32304. The heat-treatments were performed at four temperatures $\left(300^{\circ} \mathrm{C}, 600^{\circ} \mathrm{C}, 900^{\circ} \mathrm{C}\right.$ and $\left.1000^{\circ} \mathrm{C}\right)$ with two treatment times $(1 \mathrm{~h}$ and $6 \mathrm{~h}$ ) and two processes of cooling down (in air and water). The samples were studied by X-ray diffraction using Pawley method to determine the lattice parameters, mean crystallite sizes and microstrain for the two phases and compared to Vickers microhardness results.
\end{abstract}

\section{Resumo}

Os aços inoxidáveis duplex se caracterizam por apresentar uma boa combinação de propriedades mecânicas e resistência à corrosão. Devido ao equilíbrio metaestável das fases ferrítica ( $\alpha$ ) e autenítica ( $\mathrm{Y})$, podem ocorrer alterações significativas na microestrutura desses aços quando submetidos à temperaturas diferentes da ambiente, degradando suas propriedades. Neste trabalho foram investigadas as influências de tratamentos térmicos sobre a microestrutura e propriedades do aço inoxidável duplex UNS-S32304. Os tratamentos térmicos foram realizados em quatro temperaturas $\left(300^{\circ} \mathrm{C}, 600^{\circ} \mathrm{C}, 900^{\circ} \mathrm{C}\right.$ e $1000^{\circ} \mathrm{C}$ ) com dois tempos de tratamento ( $1 \mathrm{~h} \mathrm{e} 6 \mathrm{~h}$ ) e dois tipos de resfriamento (em ar e em água), além do material no estado como recebido. As amostras foram estudadas por difração de raios $\mathrm{X}$, com análise de dados pelo método de Pawley, visando determinar os parâmetros de rede, tamanhos médios de cristalitos e microdeformação para as duas fases. Estes dados foram confrontados com medidas de microdureza Vickers.

Keywords: Duplex stainless steels, Vickers microhardness, X-ray diffraction.

\section{Introduction}

Duplex stainless steels are defined as a family of steels that have a microstructure composed of two phases, austenite and ferrite, where each phase is present with significant quantity. Compared to austenitic stainless steels, duplex steels present several advantages, such as high mechanical strength, good corrosion resistance and low cost, due to lower nickel content [1,2].

Due to the combination of high mechanical properties and good corrosion resistance, duplex stainless steels are often used in corrosive environments [1]. This class of steels presents a metastable coexistence of ferritic $(\alpha)$ and austenitic ( $\mathrm{Y}$ ) phases and, consequently, the microstructure can change when submitted to temperatures out of the recommended ambient range.
For example, during welding, parts of the material are subjected to high temperatures. Also, undesirable accidental heating during working may occur, degrading their properties and compromising the integrity of components made with these steels.

In its production, a completely ferritic microstructure is formed during the solidification, followed by the partial transformation to austenite on cooling, with the precipitation of the austenite inside the ferritic matrix [2]. This process is followed by hot-rolling and subsequent annealing, where the microstructure is conserved in the biphasic field of the $\mathrm{Fe}-\mathrm{Ni}-\mathrm{Cr}$ phase diagram, consisting of alternating lamellae of ferrite and austenite [3]. The duplex stainless steels are then processed by hot rolling or forging, cold rolling, followed by a suitable annealing 
and quenching tempering to balance the ratio of the two phases.

The two basic phases of the duplex steels, austenite and ferrite, have different crystal structures: the first one has a face centered cubic structure, while the last one has a body centered cubic structure. In general, it is considered that the ideal properties of duplex steels can occur within the range of 30 to $70 \%$ of ferrite. However, the ideal proportion of the phases is 50:50 [3].

\section{Materials and Methods}

The material studied in this work was a low-alloy duplex stainless steel UNS S32304. The material was received as rolled plates, with dimensions of $72.0 \mathrm{~mm}$ wide by $1.8 \mathrm{~mm}$ thick. Table 1 shows the chemical composition reported by the manufacturer.

Table 1 - Elemental composition of the "as received" steel, reported by the manufacturer (in ppm for $\mathrm{N}$ and weight \% for the other elements).

\begin{tabular}{|l|l|l|l|l|l|}
\hline $\mathbf{C}$ & $\mathbf{C u}$ & $\mathbf{S i}$ & $\mathbf{M n}$ & $\mathbf{C r}$ & $\mathbf{M o}$ \\
\hline 0.016 & 0.4171 & 0.250 & 1.40 & 22.20 & 0.255 \\
\hline $\mathbf{N i}$ & $\mathbf{N}(\mathrm{ppm})$ & $\mathbf{S}$ & $\mathbf{P}$ & $\mathbf{T i}$ & $\mathbf{C o}$ \\
\hline 3.52 & 1030 & 0.001 & 0.023 & 0.0041 & 0.090 \\
\hline
\end{tabular}

\section{Heat-treatments}

The samples were cut from the UNS S32304 duplex steel plate in a saw with diamond disk, with $15 \times 15 \mathrm{~mm}$ dimensions and each sample was numbered for identification. Four heat treatment temperatures $\left(300^{\circ} \mathrm{C}\right.$, $600^{\circ} \mathrm{C}, 900^{\circ} \mathrm{C}$ and $1000^{\circ} \mathrm{C}$ ) were used, with two treatment times for each chosen temperature ( $1 \mathrm{~h}$ and 6 h) and two types of cooling down (in air or in water). Thus, 17 sample conditions were established: 4 temperatures $\times 2$ treatment times $\times 2$ types of cooling, plus one in the "as received" condition. The samples were then named: $3001 \mathrm{hAir}, 3001 \mathrm{hH} 2 \mathrm{O}, 3006 \mathrm{hAir}$, $3006 \mathrm{hH} 2 \mathrm{O}, \quad 6001 \mathrm{hAir}, \quad 6001 \mathrm{hH} 2 \mathrm{O}, \quad 6006 \mathrm{hAir}$, 6006hH2O, 9001hAir, $9001 \mathrm{hH} 2 \mathrm{O}, 9006 \mathrm{~h}$ Air, $9006 \mathrm{hH} 2 \mathrm{O}, 10001 \mathrm{hAir}, 10001 \mathrm{hH} 2 \mathrm{O}, 10006 \mathrm{hAir}$, $10006 \mathrm{hH} 2 \mathrm{O}$ and $\mathrm{AR}$, where in each identification the initial number represents the heat-treatment temperature (in ${ }^{\circ} \mathrm{C}$ ), followed by the treatment time (hours) and the type of cooling (air or $\mathrm{H}_{2} \mathrm{O}$ ) in addition to the "as received" (AR) sample. Each sample was embedded in cold resin and prepared by paper sanding (\#400, \#600, \#1000), followed by polishing with 9, 5 and $1 \mu \mathrm{m}$ diamond paste.

\section{Microhardness}

Vickers microhardness measurements were performed in each phase of the polished samples to obtain the hardness curves as a function of the heat treatment conditions. The measurements were performed in a Shimadzu microdurometer, with ten measurements in each phase of each sample, for statistical analysis. In the test, a load of $98.07 \mathrm{mN}$ was applied for $15 \mathrm{~s}$ per indentation and the measurements were analyzed using HMV-AD software.

\section{X-ray Diffraction}

The samples were analyzed by X-ray diffraction, in order to identify the crystal phases and analyze their microstructures. The measurements were performed in a Rigaku ULTIMA-IV X-ray diffractometer, using CuK $_{\alpha}$ radiation. The phases were identified by comparison with PDF-ICDD [4] database and the diffraction patterns were analyzed by Pawley method using TOPAS academic program [5]. From Pawley method [6] it is possible to adjust the calculated diffraction profile to the experimental profile without extracting intensities. This method of adjustment is better than Rietveld refinement [7] when the sample presents preferred orientation. From the calculated profiles it was obtained lattice parameters, mean crystallite sizes and microstrain.

\section{Results and discussion}

\section{Vickers Microhardness}

The results for Vickers microhardness are shown in Table 1.

Table 1: Average results of 10 measurements of Vickers microhardness for austenite and ferrite phases.

\begin{tabular}{|c|c|c|}
\hline Sample & HV Austenite & HV Ferrite \\
\hline AR & 371.4 & 277.6 \\
\hline 3001hAir & 328.1 & 233.0 \\
\hline 3001hH2O & 348.0 & 286.4 \\
\hline 3006hAir & 449.2 & 325.2 \\
\hline 3006hH2O & 356.1 & 236.4 \\
\hline 6001hAir & 325.7 & 258.3 \\
\hline 6001hH2O & 347.7 & 269.7 \\
\hline 6006hAir & 470.0 & 352.2 \\
\hline 6006hH2O & 380.6 & 331.4 \\
\hline 9001hAir & 332.6 & 278.5 \\
\hline 9001hH2O & 344.3 & 278.2 \\
\hline 9006hAir & 492.7 & 364.3 \\
\hline 9006hH2O & 350.7 & 268.3 \\
\hline 10001hAir & 336.6 & 257.5 \\
\hline 10001hH2O & 328.4 & 291.1 \\
\hline 10006hAir & 455.5 & 359.4 \\
\hline 10006hH2O & 326.7 & 265.7 \\
\hline
\end{tabular}

\section{X-ray Diffraction}

Figure 1 shows the X-ray diffraction (XRD) patterns for the 17 samples, plotted in 3D perspective. From the XRD profiles just the expected austenite and ferrite phases were identified, with no additional phases. Although the precipitated phases may be present, their amounts are below the detection limit of the technique. This indicates that the technique is not suitable for the determination of expected precipitates in heat-treated duplex stainless steels.

Figure 2 shows the lattice parameters for austenite and ferrite phases as a function of temperature for all treatments. It can be observed significant variations of lattice parameters for both phases with varying temperature. 
Table 2: Results for lattice parameters (a in Angstrom), mean crystallite sizes ( $\mathbf{D}$ in nanometer) for the austenite and ferrite phases, for the heat treated samples, obtained by Pawley refinement.

\begin{tabular}{|c|c|c|c|c|c|}
\hline \multicolumn{3}{|c|}{$\alpha-F e($ Air - 1h) } & \multicolumn{3}{|c|}{$\alpha-F e($ Air - 6h) } \\
\hline $\mathrm{T}\left({ }^{\circ} \mathrm{C}\right)$ & $\mathbf{a}(\AA)$ & $D(n m)$ & $\mathbf{T}\left({ }^{\circ} \mathbf{C}\right)$ & a $(\AA)$ & $D(\mathrm{~nm})$ \\
\hline 300 & 2.87570 & 89.2 & 300 & 2.87881 & 29.0 \\
\hline 600 & 2.87811 & 42.5 & 600 & 2.88046 & 20.7 \\
\hline 900 & 2.87762 & 50.7 & 900 & 2.87902 & 31.3 \\
\hline 1000 & 2.87810 & 48.1 & 1000 & 2.87913 & 24.7 \\
\hline \multicolumn{3}{|c|}{ Y-Fe (Air - 1h) } & \multicolumn{3}{|c|}{ Y-Fe (Air - 6h) } \\
\hline $\mathrm{T}\left({ }^{\circ} \mathrm{C}\right)$ & a $(\AA)$ & $D(n m)$ & $\mathbf{T}\left({ }^{\circ} \mathbf{C}\right)$ & a $(\AA)$ & $D(\mathrm{~nm})$ \\
\hline 300 & 3.60230 & 78.5 & 300 & 3.60539 & 30.0 \\
\hline 600 & 3.60473 & 41.8 & 600 & 3.60391 & 24.3 \\
\hline 900 & 3.60263 & 46.8 & 900 & 3.60416 & 31.5 \\
\hline 1000 & 3.60379 & 48.2 & 1000 & 3.60325 & 28.1 \\
\hline \multicolumn{3}{|c|}{$\alpha-\mathrm{Fe}(\mathrm{H} 2 \mathrm{O}-1 \mathrm{~h})$} & \multicolumn{3}{|c|}{$\alpha-\mathrm{Fe}(\mathrm{H} 2 \mathrm{O}-6 \mathrm{~h})$} \\
\hline $\mathrm{T}\left({ }^{\circ} \mathrm{C}\right)$ & a $(\AA)$ & $D(n m)$ & $\mathbf{T}\left({ }^{\circ} \mathbf{C}\right)$ & a $(\AA)$ & $D(\mathrm{~nm})$ \\
\hline 300 & 2.87483 & 51.0 & 300 & 2.88011 & 20.8 \\
\hline 600 & 2.87749 & 37.6 & 600 & 2.87915 & 22.1 \\
\hline 900 & 2.87733 & 39.4 & 900 & 2.87995 & 19.8 \\
\hline 1000 & 2.87769 & 49.0 & 1000 & 2.87999 & 20.3 \\
\hline \multicolumn{3}{|c|}{ y-Fe (H2O - 1h) } & \multicolumn{3}{|c|}{ v-Fe (H2O - 6h) } \\
\hline $\mathrm{T}\left({ }^{\circ} \mathrm{C}\right)$ & a $(\AA)$ & $D(n m)$ & $\mathbf{T}\left({ }^{\circ} \mathbf{C}\right)$ & a $(\AA)$ & $D(n m)$ \\
\hline 300 & 3.60107 & 56.2 & 300 & 3.60660 & 22.0 \\
\hline 600 & 3.60385 & 46.1 & 600 & 3.60317 & 24.7 \\
\hline 900 & 3.60188 & 44.2 & 900 & 3.60453 & 21.7 \\
\hline 1000 & 3.60355 & 55.2 & 1000 & 3.60449 & 25.6 \\
\hline
\end{tabular}

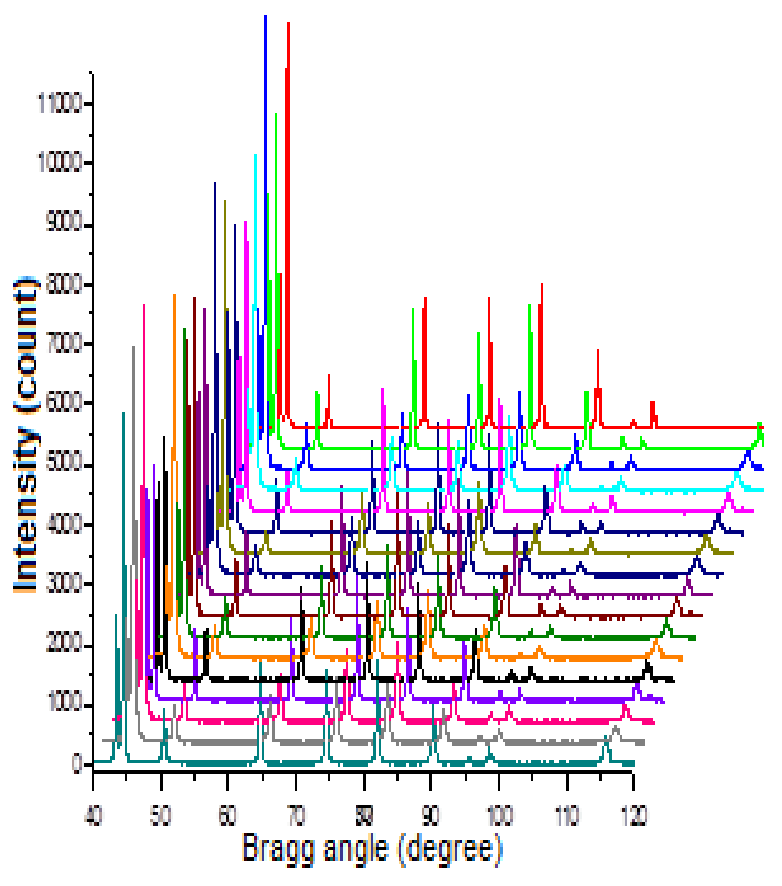

Figure 1: X-ray diffraction profiles for the 17 samples plotted in 3D.
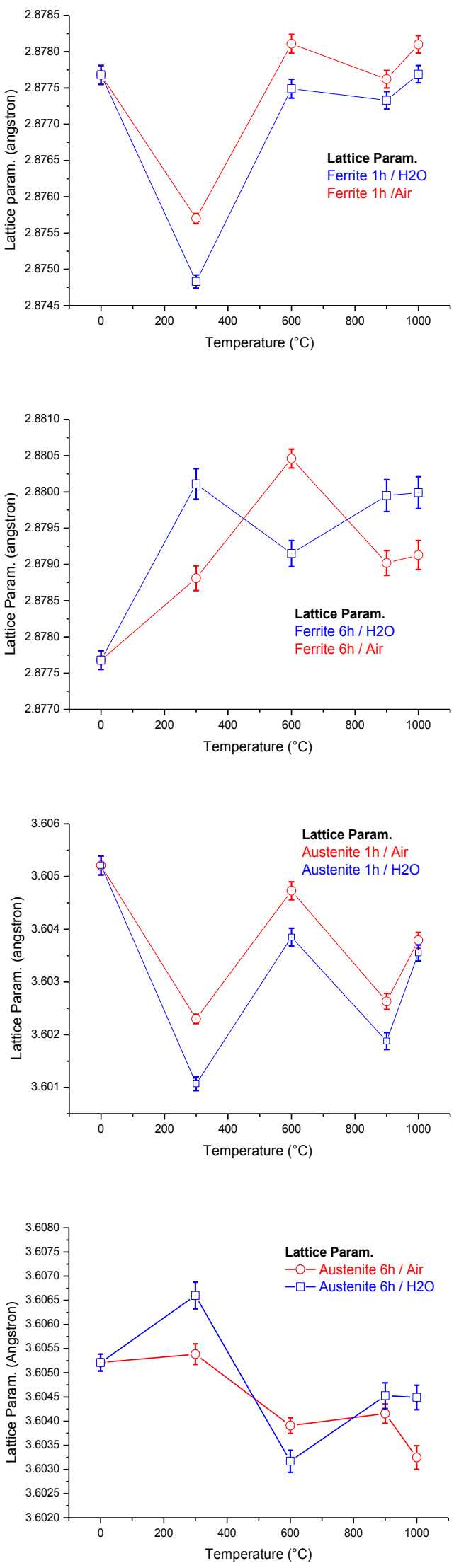

Figure 2: Results of lattice parameters for austenite and ferrite phases for varying temperature. The temperature $0^{\circ}$ corresponds to the "as received" sample. 


\section{Conclusions}

It can be concluded that the heat treatments changed the properties and the microstructure of duplex stainless steel UNS S32304. Vickers microhardness measurements indicated changes in the properties of ferrite and austenite phases due to the heat-treatments. From X-ray diffraction analysis changes in lattice parameters, mean crystallite sizes and microstrain are clearly visible for the ferrite and austenite phases due to the heat-treatments.

\section{Acknowledgment}

The authors would like to thank Metallurgy and Materials Engineering Dept. of EPUSP by microhardness measurements, MSc. E. P. Soares and Dr. H. Takiishi from IPEN for helping in the heattreatments and to Dr. M. T. D. Orlando from Universidade Federal do Espírito Santo for providing the samples.

\section{References}

[1] MACHADO, C. S. C. Perfis de tensão residual do aço duplex UNS S32304 submetido a diferentes processos de soldagem TIG e condições de tratamento térmico. Master Thesis (in portuguese), Universidade Federal do Espírito Santo; Vitória, ES (2015).

[2] GUNN, R. N. Duplex stainless steel: microstructure, properties and application. Abington Publishing. Cambridge, (2003).

[3] IMOA- Practical guidelines for the fabrication of duplex stainless steels, International Molybdenum Association (IMOA), London (2009).

[4] ICDD (2003). Powder Diffraction File Inorganic and Organic Data Book, edited by Dr. Soorya Kabekkodu (International Centre for Diffraction Data, Newtown Square, PA USA).

[5] COELHO, A A; TOPAS Academic Version 4.1 Technical Reference (2007).

[6] PAWLEY, G. S. Unit-Cell Refinement From Powder Diffraction Scans . J. Appl. Cryst. 14, 357-361 (1981).

[7] RIETVELD, H. M. A profile refinement method for nuclear and magnetic structures. Journal of Applied Crystallography, v. 2, p. 65 -71 (1969). 